\title{
PENGARUH KECEPATAN PENGADUKAN DAN JARAK ELEKRODA TERHADAP PENURUNAN KADAR COD DAN TSS PADA LIMBAH BATIK MENGGUNAKAN METODE ELEKTROKOAGULASI
}

\section{Hammami Fajar Kurniawan}

Fakultas Teknik Universitas Muhammadiyah Surakarta Jawa Tengah, Indonesia

Email: kurniawanhammami83@gmail.com

\begin{abstract}
Abstrak
Keberadaan industri tekstil khususnya pada produksi batik di daerah pasti akan memberikan keuntungan pada daerah tersebut, karena bisa menyerap tenaga kerja dari daerah tersebut. Akan tetapi dimana ada keuntungan maka disitu juga akan terdapat kekurangan, seperti halnya pada pabrik tekstil ini yang mana limbah cair yang di hasilkan memberikan dampak negatif pada lingkungan. Limbah cair ini berasal dari proses pencucian dan pewarnaan yang mengandung zat warna, logam berat, dan konsentrasi garam yang tinggi. Penelitian ini mengkji limbah batik dari pabrik tekstil menggunakan metode elektrokoagulasi dengan elektroda alumunium. Penelitian pengolahan limbah cair batik telah dilakukan. Hasil dari penelitian ini membuktikan bahwa variabel jarak elektroda dan kecepatan pengadukan mempengaruhi nilai efisiensi penurunan COD dan nilai penurunan TSS pada limbah batik. Secara umum, semakin tinggi kecepatan pengadukan dan semakin dekat jarak antar elektroda, semakin tinggi pula efisiensi penurunan TSS dan COD. Terdapat titik optimal untuk kecepatan pengadukan, yang mana penurunan efisiensi TSS dan COD tertinggi diperoleh pada kecepatan pengadukan $200 \mathrm{rpm}$. Dari variabel yang di kaji, didapatkan nilai optimal pada kedua variabel yaitu pada jarak elektroda 1,6 dan pada kecepatan pengadukan $200 \mathrm{rpm}$, dengan hasil nilai efisiensi yang di dapat yaitu pada penurunan COD sebesar $89,39 \%$ dan pada penurunan TSS sebesar $90,45 \%$.
\end{abstract}

Kata Kunci: limbah batik; elektrokoagulasi; effisiensi; elektroda

\section{Abstract}

The existence of the textile industry, especially in batik production in the region, will certainly provide benefits to the area, because it can absorb labor from the area. However, where there are advantages, there will also be disadvantages, as is the case in this textile factory where the liquid waste produced has a negative impact on the environment. This liquid waste comes from the washing and coloring process which contains dyes, heavy metals, and high salt concentrations. This study examines batik waste from a textile factory using the electrocoagulation method with aluminum electrodes. Research on batik wastewater treatment has been carried out. The results of this study prove that the electrode distance and stirring speed variables affect the COD reduction efficiency and TSS reduction in batik waste. In general, the higher the stirring speed and the closer the electrode spacing, the higher the TSS and COD reduction efficiency. There is an optimal point for stirring speed,

$\begin{array}{ll}\text { How to cite: } & \text { Kurniawan, H, F., (2021) Pengaruh Kecepatan Pengadukan dan Jarak Elekroda terhadap Penurunan } \\ & \text { Kadar COD dan TSS pada Limbah Batik Menggunakan Metode Elektrokoagulasi, Syntax Idea, 3(11), } \\ & \text { https:// doi.org/10.36418/syntax-idea.v3i11.1578 } \\ \text { E-ISSN: } & 2684-883 \mathrm{X} \\ \text { Published by: } & \text { Ridwan Institute }\end{array}$


where the highest reduction in TSS and COD efficiency is obtained at a stirring speed of $200 \mathrm{rpm}$. From the variables studied, the optimal value for both variables was obtained, namely at the electrode distance of 1.6 and at a stirring speed of 200 rpm, with the result that the efficiency value obtained was a decrease in COD of $89.39 \%$ and a decrease in TSS of $90.45 \%$.

Keywords: batik waste; electrocoagulation; efficiency; electrode

\section{Pendahuluan}

Di dirikannya suatu industri pada suatu daerah akan memberikan dampak positif dan negatif. salah satu dampak positifnya yaitu terdapatnya penyerapan tenaga kerja dan memberikan pemasukan pada daerah tersebut, sedangkan untuk dampak negatifnya sendiri yaitu terdapatnya limbah yang dihasilkan yang mana dapat membahayakan lingkungan tersebut (Supriatna, Jumiati, \& Waseh, 2018).

Peraturan Badan Lingkungan Hidup Pemerintah Kota Surakarta tahun 2016, air sungai kelas 2 yaitu air yang peruntukannya dapat digunakan untuk pengelolaan ikan air tawar, peternakan dan air untuk mengairi pertanaman. Kondisi air yang tercemar tersebut dampak dari pengolahan pembuangan air limbah batik yang belum dilakukan sesuai prosedur (Rumaisa, Christy, \& Hermanto, 2019).

Berdasarkan data rekapitulasi kualitas air sungai Kota Surakarta, terdapat pengambilan sampel di berbagai lokasi. Pada daerah Kaliayar Tengah dimana sungai tersebut berdampak pada pembuangan air limbah tekstil. Berdasarkan parameter secara kimia yang diperoleh, air sungai pada daerah Kaliayar memliki pH 6,65 (mg/L); TSS 15 (mg/L); DO 1,6 (mg/L); BOD 16,4 (mg/L); COD 36,9 (mg/L); PO4 0,8582 (mg/L) (Rumaisa et al., 2019).

Pada beberapa tahun terakhir telah dikembangkan sebuah metode yaitu elektrokoagulasi yangmana metode tersebut sangat efektif untuk mengolah limbah cair dari industri tekstil. Metode ini efisien diterapkan untuk pengolahan air limbah yang mengandung logam berat, bahan makanan, minyak, pewarna tekstil, bahan organik, dan polutan lain. Elektrokoagulasi merupakan gabungan dari proses elektrokimia serta koagulasi-flokulasi (Nurafiah S, 2018). Metode ini menggunakan sel elektrokimia, yang berupa dua elektroda, yakni katoda dan anoda, yang direndam dalam larutan konduktif atau elektrolit dan dihubungkan bersama melalui rangkaian listrik yang tersambung dengan sumber arus dan perangkat control (Nurafiah S, 2018). Dalam sel elektrokoagulasi terjadi reaksi oksidasi di anoda sementara reaksi reduksi di katoda. Material elektroda yang paling banyak digunakan adalah alumunium karena memiliki nilai resistivitas yang kecil sehingga dapat mengalirkan arus listrik lebih baik jika dibandingkan dengan material lain. Pada anoda, terjadi oksidasi terhadap ion negatif sehingga membentuk $\mathrm{Al}$ + yang akan berikatan dengan $\mathrm{OH}$ - membentuk koagulan $\mathrm{Al}$ $\mathrm{OH}$ 3. Sementara itu, gas hidrogen yang dihasilkan di katoda membantu flok terangkat ke permukaan. Ikatan antara koagulan dengan polutan yang terdapat dalam air limbah inilah yang dapat mengurangi kadar pencemaran limbah batik sebelum akhirnya dibuang ke lingkungan. Penelitian ini mempelajari pengolahan limbah batik dengan 
metode elektrokoagulasi menggunakan elektroda alumunium. Secara khusus, pengaruh variabel kecepatan pengadukan dan jarak elektroda terhadap kualitas limbah setelah treatment dipelajari. Kualitas limbah cair batik diukur dari kadar TSS dan COD (Ayu, 2018).

\section{Metode Penelitian}

Penelitian yang dilakukan bertujuan untuk mengetahui Pengaruh Kecepatan Pengadukan dan Jarak Elektroda pada metode Elektrokoagulasi Terhadap Penurunan Kadar Cod Dan Tss Limbah Batik. Rancangan yang digunakan pada penelitian ini yaitu rancangan acak lengkap (RAL). Analisis yang dilakukan berupa analisis kuntitatif menggunakan metode reflux (Hengki Adi Saputra, Badariah, \& Novalyan, 2019).

Proses pengambilan data dilakukan di Laboratorium Teknik Kimia Universitas Jenderal Soedirman dengan sampel berupa air limbah industri batik Sokaraja. Metode yang digunakan yaitu elektrokoagulasi dengan elektroda alumunium serta memvariasikan waktu pengadukan dan jarak elektroda. Kajian selanjutnya yaitu membandingkan data hasil yang diperoleh dengan literatur jurnal pendukung serta hasil penelitian elektrokoagulasiyang pernah dilakukan sebelumnya (Devy \& Haryanto, 2021).

\section{Hasil dan Pembahasan}

\section{A. Hasil}

Sampel yang digunakan pada penelitian ini berupa limbah batik sokaraja yang diambil dari Desa Sokaraja Kulon yang berada di Kecamatan Sokaraja, Banyumas, Jawa Tengah. Sampel yang digunakan di uji kadar COD dan kadar TSS dengan memvariasikan variabel kecepatan pengadukan dan jarak elektroda. Hasil yang didapatkan setelah melalukan uji sebagai berikut.

Tabel 1

Data uji Kadar COD dan kadar TSS

\begin{tabular}{|c|c|c|c|c|c|}
\hline $\begin{array}{c}\text { Jarak } \\
\text { Elektroda } \\
(\mathrm{cm})\end{array}$ & $\begin{array}{c}\text { Kecepatan } \\
\text { Pengadukan } \\
\text { (rpm) }\end{array}$ & $\begin{array}{c}\text { Kadar } \\
\text { COD } \\
(\mathrm{mg} / \mathrm{L})\end{array}$ & $\begin{array}{c}\text { Efisiensi } \\
\text { Penurunan } \\
\text { Kadar } \\
\text { COD } \\
(\%)\end{array}$ & $\begin{array}{c}\text { Kadar } \\
\text { TSS } \\
(\mathrm{mg} / \mathrm{L})\end{array}$ & $\begin{array}{c}\text { Efisiensi } \\
\text { Penurunan } \\
\text { Kadar } \\
\text { TSS } \\
(\%) \\
\end{array}$ \\
\hline \multirow{5}{*}{1,6} & 200 & 74,15 & 89,39 & 476 & 86,87 \\
\hline & 400 & 125 & 82,12 & 470 & 87,03 \\
\hline & 600 & 169,49 & 75,75 & 436 & 87,97 \\
\hline & 800 & 211,86 & 69,69 & 418 & 88,47 \\
\hline & 1000 & 275,42 & 60,60 & 346 & 90,45 \\
\hline \multirow{5}{*}{3,2} & 200 & 190,67 & 72,72 & 562 & 84,50 \\
\hline & 400 & 252,11 & 63,93 & 534 & 85,27 \\
\hline & 600 & 298,72 & 57,27 & 510 & 85,93 \\
\hline & 800 & 349,57 & 50 & 474 & 86,92 \\
\hline & 1000 & 381,35 & 45,45 & 442 & 87,81 \\
\hline
\end{tabular}




\begin{tabular}{|c|c|c|c|c|c|}
\hline $\begin{array}{c}\text { Jarak } \\
\text { Elektroda } \\
\text { (cm) }\end{array}$ & $\begin{array}{l}\text { Kecepatan } \\
\text { Pengadukan } \\
\quad(\text { rpm) }\end{array}$ & $\begin{array}{c}\text { Kadar } \\
\text { COD } \\
(\mathrm{mg} / \mathrm{L})\end{array}$ & $\begin{array}{c}\text { Efisiensi } \\
\text { Penurunan } \\
\text { Kadar } \\
\text { COD } \\
(\%) \\
\end{array}$ & $\begin{array}{c}\text { Kadar } \\
\text { TSS } \\
(\mathrm{mg} / \mathrm{L})\end{array}$ & $\begin{array}{c}\text { Efisiensi } \\
\text { Penurunan } \\
\text { Kadar } \\
\text { TSS } \\
(\%)\end{array}$ \\
\hline \multirow{5}{*}{4,8} & 200 & 381,35 & 45,45 & 694 & 80,86 \\
\hline & 400 & 402,54 & 42,42 & 624 & 82,79 \\
\hline & 600 & 423,72 & 39,39 & 598 & 83,50 \\
\hline & 800 & 434,32 & 37,87 & 552 & 84,77 \\
\hline & 1000 & 497,88 & 28,78 & 524 & 85,54 \\
\hline \multirow{5}{*}{6,4} & 200 & 423,72 & 39,39 & 792 & 78,15 \\
\hline & 400 & 434,32 & 37,87 & 758 & 79,09 \\
\hline & 600 & 466,10 & 33,33 & 710 & 80,41 \\
\hline & 800 & 540,25 & 22,72 & 670 & 81,52 \\
\hline & 1000 & 582,62 & 16,66 & 664 & 81,68 \\
\hline \multirow{5}{*}{8} & 200 & 487,28 & 30,30 & 946 & 73,91 \\
\hline & 400 & 519,06 & 25,75 & 840 & 76,83 \\
\hline & 600 & 572,03 & 18,18 & 802 & 77,88 \\
\hline & 800 & 614,40 & 12,12 & 794 & 78,10 \\
\hline & 1000 & 646,18 & 7,57 & 726 & 79,97 \\
\hline
\end{tabular}

\section{Kualitas Limbah Batik Sokaraja}

Sampel yang digunakan dalam riset ini merupakan limbah batik yang diambil dari Desa Sokaraja Kulon yang terletak di Kecamatan Sokaraja, Banyumas, Jawa Tengah. sampel yang digunakan hendak dicoba proses elektrokoagulasi. Pada riset ini proses elektrokoagulasi memakai elektroda (Al) / (Al). Proses elektrokoagulasi dicoba dengan alterasi kecepatan pengadukan dan jarak elektroda dengan parameter yang dianalisis merupakan kandungan COD serta kandungan TSS.

Saat sebelum diberi perlakuan dengan proses elektrokoagulasi, sampel limbah batik dianalisis kandungan COD serta kandungan TSS terlebih dulu buat mengenali mutu dari limbah tersebut. Hasil analisis limbah bisa dilihat pada tabel $\mathrm{x}$.

Tabel 2

Kualitas awal limbah batik Sokaraja

\begin{tabular}{ccccc}
\hline \multicolumn{2}{c}{ Parameter } & Satuan & Hasil uji & $\begin{array}{c}\text { Baku mutu } \\
\text { Air limah } \\
\text { tekstil }\end{array}$ \\
\hline $\begin{array}{c}\text { Limbah } \\
\text { Batik }\end{array}$ & $\mathrm{COD}$ & $\mathrm{Mg} / \mathrm{L}$ & 699,15 & 150 \\
\cline { 2 - 5 } & $\mathrm{TSS}$ & $\mathrm{Mg} / \mathrm{L}$ & 3626 & 50 \\
\hline
\end{tabular}

Bersumber pada tabel 2, bisa dikenal kalau limbah tersebut tidak layak dibuang langsung ke area sebab nilai COD serta TSS yang sangat besar melebihi baku kualitas air limbah. Dengan demikian limbah butuh diberi perlakuan saat sebelum dibuang ke area. Salah satu perlakukan yang dicoba merupakan dengan proses elektrokoagulasi memakai elektroda Aluminium (Suhartini \& Nurika, 2018). 


\section{B. Pembahasan}

TSS merupakan partikel yang tertahan pada glass fiber filter dengan ukuran kurang dari atau sama dengan $2 \mu \mathrm{m}$. Partikel yang dimaksud meliputi baik zat organik maupun anorganik seperti alga, nutrien, dan logam. Hasil pengujian limbah batik sebelum di-treatment memiliki kadar TSS 362 mg/L, dan COD sebesar 699,15 mg/L (Rahmayanti \& Mujiburohman, 2020). Menurut Keputusan Menteri Negara Lingkungan Hidup No. KEP-51/MENLH/10/1995, batas ambang TSS dan COD dalam limbah detergent masing-masing $100 \mathrm{mg} / \mathrm{L}$ dan $300 \mathrm{mg} / \mathrm{L}$ (Rahmayanti \& Mujiburohman, 2020). Setelah dilakukan treatment variasi kecepatan pengadukan dan jarak elektroda, terjadi penurunan kadar TSS dengan efisiensi penurunan sebagaimana ditunjukkan pada Gambar 1.

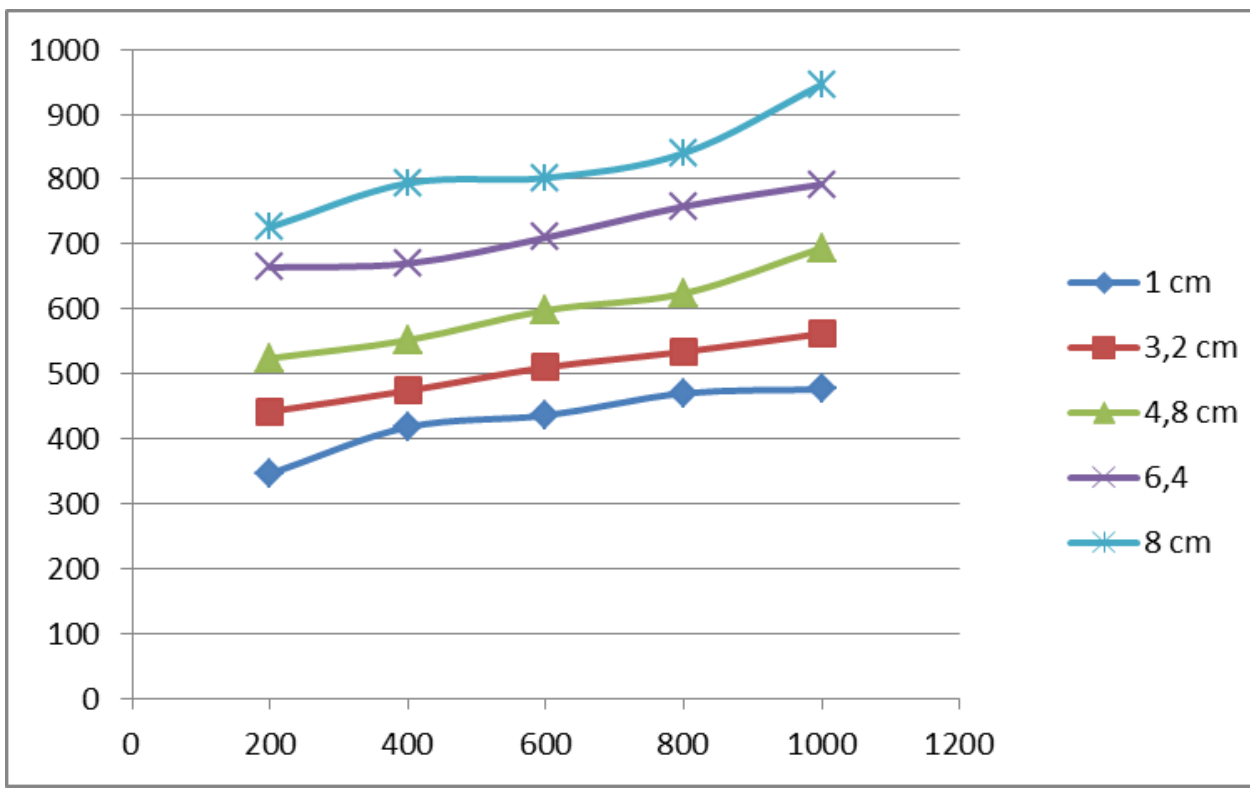

Gambar 1

Efisiensi Penurunan Kadar TSS (\%) Setiap Variasi

Dari Gambar 1 dapat dilihat bahwa setelah elektrokoagulasi dijalankan, efisiensi penurunan kadar TSS semakin turun dengan naiknya kecepatan pengadukan. Hal ini dapat dijelaskan dari konsep tumbukan bahwa peningkatan kecepatan pengadukan, di satu sisi, bisa menaikkan frekuensi tumbukan antara koagulan dengan partikel-partikel sekitarnya membentuk flok. Selama proses elektrokoagulasi elekroda Al mengalami oksidasi (melepas elektronnya) menjadi $\mathrm{Al3}+$ yang kemudian berikatan dengan $\mathrm{OH}$ - dari air membentuk $\mathrm{Al}(\mathrm{OH}) 3$ yang berfungsi sebagai koagulan (Tety Sudiarti, Eko Prabowo Hadisantoso, \& Asep Supriadin, 2018). Dengan kecepatan pengadukan yang semakin tinggi, gerakan koagulan untuk mengikat polutan melalui tumbukan antar partikel juga akan semakin besar. Hal inilah yang menyebabkan semakin besar kecepatan pengadukan yang dipakai maka akan semakin banyak pula flok yang dihasilkan, yang akhirnya menurunkan kadar TSS. Akan tetapi, jika kecepatan pengadukan terlalu tinggi, 
tumbukan yang dihasilkan antar partikel justru dapat melepaskan ikatan flokulan dan kembali menjadi partikel-partikel kecil dalam air (suspended solid) (Humairoh, 2014).

Dari gambar yang sama terlihat bahwa semakin berdekatan elektroda, semakin tinggi efisiensi penurunan TSS. Hal ini terkait dengan jarak lintasan arus listrik bahwa semakin tinggi panjang lintasan, atau jarak elektroda makin jauh, nilai hambatan listriknya pun semakin besar. Pada beda potensial yang sama, arus listrik yang mengalir semakin kecil sehingga pembentukan koagulan juga semakin kecil. Tetapi, jarak yang terlalu dekat juga beresiko karena jumlah koagulan yang meningkat bisa mengganggu sistem akibat hubungan singkat elektroda. Saat elektroda dipasang pada jarak 1,6 cm, dengan kecepatan pengadukan 200, 400, 600, 800 dan $1000 \mathrm{rpm}$ didapat efisiensi yang semakin menurun, yakni 90,45\%, 88,47\%, 87,97\%, 87,03\%, dan 86,87\%. Sementara itu, saat elektroda dipasang pada jarak $3,2 \mathrm{~cm}$, efisiensi penurunan TSS mengikuti pola yang sama dengan ketika elektroda berjarak $1,6 \mathrm{~cm}$, hanya nilainya lebih rendah yang mana efisiensi tertinggi diperoleh sebesar $87,81 \%$. Pada kedua variasi jarak elektroda, semua titik optimum didapat saat kecepatan pengadukan $200 \mathrm{rpm}$ (Sari et al., 2020).

Nilai TSS tersebut masih berada diatas ambang batas baku mutu limbah cair batik. Agar nilai TSS dapat berada dibawah ambang batas baku mutu dapat dilakukan proses filtrasi dengan adanya penambahan massa koagulan salah satu contoh biji kelor. Hal tersebut disebabkan karena terdapat partikel koloid yang mempunyai muatan listrik yang stabil pada limbah batik cair, dan ketika koagulan ditambahkan maka akan mengakibatkan partikel koloid menjadi tidak stabil dan akan menyatu dengan partikel koloid yang lainnya kemudian partikel tersebut akan terendapkan. Penambaha koagulan harus sesuai dosis, apabila melebihi dosis maka kandungan TSS nya akan menurun, hal ini disebabkan partikel yang terendapkan dapat stabil kembali (Indrayani, 2018).

Pada proses koagulasi umumnya menggunakan koagulan alum dan tawas, namun pada koagulan tersebut memiliki dampak negatif pada kesehatan dan dapat mencemari lingkungan. Untuk menghindari dampak negatif tersebut, akan lebih baik bila menggunakan bahan alami seperti contoh biji kelor, biji kelor memiliki kandungan berupa protein bersifat polielektrolit kationik yang berguna untuk menjernihkan air, protein tersebut juga mengandung asam amino yang akan mengalami ionisasi atau disosiasi ketika dilarutkan dalam air. Pada penelitian yang sudah dilakukan oleh (Suryanti et al., 2019) penambahan massa koagulan sebanyak 60gr pada limbah batik mampu menurukan efektifitas TSS sebesar 91,67\% (Fadillah, 2019).

Secara kimiawi COD menunjukkan jumlah total oksigen yang dibutuhkan untuk mengoksidasi bahan organik. Pengaruh kecepatan pengadukan dan jarak elektroda terhadap penurunan COD ditunjukkan pada Gambar 2. Pengaruh kecepatan pengadukan terhadap efisiensi penurunan COD mirip dengan terhadap efisiensi penurunan TSS, bahwa semakin tinggi kecepatan pengadukan, semakin menurun efisiensi penurunan COD. Kemiripan ini terjadi karena bahan-bahan yang bisa dioksidasi secara kimiawi sebagian juga berbentuk suspended solid yang keberadaannya dipengaruhi seberapa banyak yang terikat koagulan $\mathrm{Al}(\mathrm{OH}) 3$ (Amanda, 2019). 


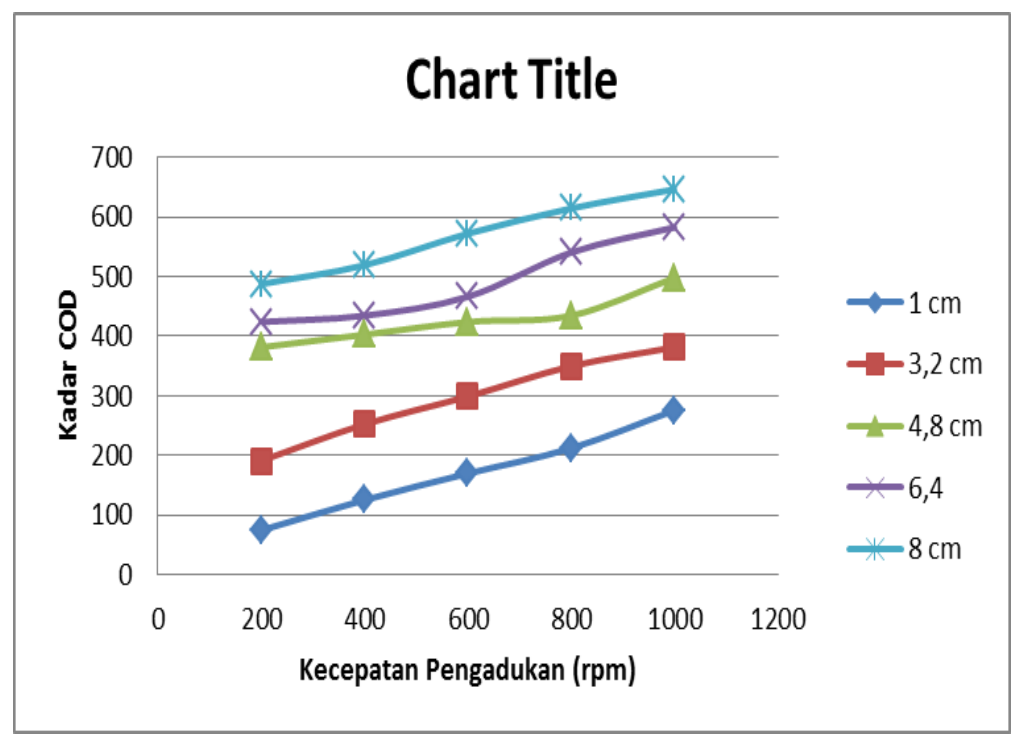

\section{Gambar 2}

\section{Efisiensi Penurunan Kadar COD (\%) Setiap Variasi}

Pada jarak elektroda 1,6 cm, dengan kecepatan pengadukan 200, 400, dan 600, 800 dan $1000 \mathrm{rpm}$ didapat efisiensi penurunan COD sebesar 89,93\%, 82,12\%, 75,75\%, $69,69 \%, 60,60 \%$. Kecenderungan yang sama terjadi saat elektroda dipasang pada jarak $8 \mathrm{~cm}$, dengan nilai yang lebih rendah, efisiensi penurunan COD yang optimal terjadi pada kecepatan pengadukan $200 \mathrm{rpm}$. Berbeda dengan kondisi awal TSS, limbah cair batik yang digunakan kebanyakan memiliki COD jauh di atas ambang batasnya. Perlu pengolahan elektrokoagulasi secara berseri untuk menghasilkan limbah laundry yang COD-nya memenuhi syarat (Rahajeng, Sumiyati, \& Samudro, 2015).

\section{Kesimpulan}

Penelitian pengolahan limbah cair batik telah dilakukan. Terbukti bahwa kecepatan pengadukan dan jarak antar elektroda mempengaruhi efisiensi penurunan TSS dan COD pada limbah cair batik. Secara umum, semakin tinggi kecepatan pengadukan dan semakin dekat jarak antar elektroda, semakin tinggi pula efisiensi penurunan TSS dan COD. Terdapat titik optimal untuk kecepatan pengadukan, yang mana penurunan efisiensi TSS dan COD tertinggi diperoleh pada kecepatan pengadukan $200 \mathrm{rpm}$. Diperoleh titik optimal pada variabel yang di pelajari yaitu pada kecepatan pengadukan $200 \mathrm{rpm}$ dan pada jarak elektroda 1,6 cm, dengan hasil efisiensi penurunan kadar TSS sebesar 90,45\% dan hasil efisiensi penurunan kadarCOD sebesar 89,39\%. 


\section{BIBLIOGRAFI}

Amanda, Yessinta Trizna. (2019). Pemanfaatan Biji Trembesi (Samanea Saman) Sebagai Koagulan Alami Untuk Menurunkan Bod, Cod, Tss, Kekeruhan Pada Pengolahan Limbah Cair Tempe (Studi di Industri Tempe UD. X Kecamatan Patrang Kabupaten Jember).Google Scholar

Ayu, Adi Puspitarini. (2018). Komparasi Recovery Aluminium Lumpur PDAM X Menggunakan Metode Elektrolisis Dengan Membran Penukar Kation Dan Membran Penukar Anion. Institut Teknologi Sepuluh Nopember. Google Scholar

Devy, Belinda Liana, \& Haryanto, A. R. (2021). Pengaruh Beda Potensial dan Waktu Kontak terhadap Penurunan Kadar COD dan TSS pada Limbah Batik menggunakan Metode Elektrokagulasi. Jurnal Teknik Kimia USU, 10(2), 63-69. Google Scholar

Fadillah, Yuliana. (2019). Analisa Pengaruh Tekanan Terhadap Nilai Efisiensi Proses Filtrasi Lumpur dengan Penambahan Koagulan Poly Aluminium Chloride (PAC) dan Al2 (SO 4) 3 Menggunakan Alat Plate and Frame Filter Press (Analysis of the Effect of Pressure on the Efficiency of the Sludge Filtration Process By Aading Poly Aluminium Chloride (PAC) and Al2 (SO4) 3 Coagulants Using a Plate and Frame Filter Press). undip vokasi. Google Scholar

Hengki Adi Saputra, Tb150968, Badariah, Badariah, \& Novalyan, Devie. (2019). Aplikasi Biosorben Dari Limbah Sabut Pinang (Areca Catechu L.) Untuk Meningkatkan Kualitas Air Sungai Batanghari. Uin Sulthan Thaha Saifuddin Jambi. Google Scholar

Humairoh, Liza. (2014). Penerapan Metode Elektrokoagulasi Dalam Penjernihan Air Sungai Musi Menggunakan Elektroda Aluminium. Politeknik Negeri Sriwijaya. Google Scholar

Indrayani, Lilin. (2018). Pengolahan limbah cair industri batik sebagai salah satu percontohan IPAL batik di Yogyakarta. Ecothropic, 12(2), 173-184. Google Scholar

Nurafiah S, Nadia. (2018). Pengolahan Limbah Cair Laboratorium Kimia dengan Metode Elektrokoagulasi dan Koagulan Biji Kelor. Universitas Islam Negeri Alauddin Makassar. Google Scholar

Rahajeng, Estuning Mugi, Sumiyati, Sri, \& Samudro, Ganjar. (2015). Pengaruh konsentrasi Chemical Oxygen Demand (COD) dan pH terhadap kinerja Granular Activated Carbon Dual Chamber Microbial Fuel Cells (GAC-DCMFCs). Jurnal Teknik Lingkungan, 4(2), 1-8. Google Scholar

Rahmayanti, Shofia, \& Mujiburohman, Muhammad. (2020). Pengaruh Kecepatan Pengadukan dan Jarak Elektroda Elektrokoagulasi Terhadap Penurunan Kadar TSS 
dan COD pada Limbah Cair Laundry. Proceeding of The URECOL, 305-308. Google Scholar

Rumaisa, Dewi, Christy, Evie, \& Hermanto, Hermanto. (2019). Fungsi Dinas Lingkungan Hidup Surakarta Dalam Pengendalian Pencemaran Sungai (Studi Pada Dinas Lingkungan Hidup Kota Surakarta). Jurnal Hukum Media Bhakti. Google Scholar

Sari, Mila, Mahyuddin, Mahyuddin, Simarmata, Marulam M. T., Susilawaty, Andi, Wati, Cheppy, Munthe, Seri Asnawati, Hidayanti, Rahmi, NNPS, Rd Indah Nirtha, Fatma, Fitria, \& Saputra, Harry Ade. (2020). Kesehatan lingkungan perumahan. Yayasan Kita Menulis. Google Scholar

Suhartini, Sri, \& Nurika, Irnia. (2018). Teknologi Pengolahan Limbah Agroindustri. Universitas Brawijaya Press. Google Scholar

Supriatna, Peri, Jumiati, Ipah Ema, \& Waseh, Hasuri. (2018). Analisis Dampak Sosial Ekonomi Kebijakan Pembangunan Pelabuhan Pt Cemindo Gemilang Terhadap Kehidupan Masyarakat Desa Darmasari Kecamatan Bayah Kabupaten Lebakbanten. Universitas Sultan Ageng Tirtayasa. Google Scholar

Tety Sudiarti, Sudiarti, Eko Prabowo Hadisantoso, Hadisantoso, \& Asep Supriadin, Supriadin. (2018). Prosiding: Seminar Nasional Kimia UIN Sunan Gunung Djati Bandung 2018 Tema:"Peran Sains Dalam Meningkatkan Nilai Tambah Bahan Alam Untuk Kesejahteraan. Masyarakat." PROSIDING: Seminar Nasional Kimia UIN Sunan Gunung Djati Bandung 2018 Tema:"Peran Sains Dalam Meningkatkan Nilai Tambah Bahan Alam Untuk Kesejahteraan., 1(1), 1-227. http://digilib. uinsgd. ac. id. Google Scholar

\section{Copyright holder:}

Hammami Fajar Kurniawan (2021)

First publication right:

Syntax Idea

This article is licensed under:

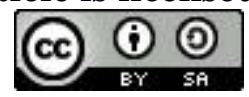

